\title{
CECR1 p.Gly47Arg mutations are not increased in frequency in Turkish Behçet's disease patients compared with healthy controls
}

\author{
B Erer ${ }^{1 *}$, E Remmers ${ }^{2}$, M Takeuchi ${ }^{2}$, D Ustek ${ }^{3}$, I Tugal-Tutkun ${ }^{4}$, E Seyahi ${ }^{5}$, Y Ozyazgan ${ }^{5}$, A Gul ${ }^{1}$, M Ombrello ${ }^{6}$, \\ D Kastner ${ }^{2}$
}

From 8th International Congress of Familial Mediterranean Fever and Systemic Autoinflammatory Diseases Dresden, Germany. 30 September - 3 October 2015

\section{Question}

In Behçet's disease (BD), vasculitis involving blood vessels of nearly all sizes and types may underlie the diverse tissue and organ involvement. Loss of function mutations in the CECR1 gene (encoding adenosine deaminase 2) have recently been shown to cause a recessive genetic disease, deficiency of adenine deaminase 2 (DADA2). Patients with DADA2 exhibit systemic vasculopathy characterized by intermittent fevers, skin rash, and neurovascular manifestations along with other features that can lead to a diagnosis of polyarteritis nodosa. Patients homozygous for the CECR1 p.Gly47Arg mutation are reported in two nonconsanguineous Turkish families and this mutation is found at low frequency in the Turkish population. We therefore attempted to determine whether some $\mathrm{BD}$ cases may be explained by adenosine deaminase 2 deficiency and whether this mutation contributes to BD risk in patients of Turkish ancestry.

\section{Methods}

Turkish BD patients $(\mathrm{n}=1,609)$ and controls $(\mathrm{n}=1,519)$ were genotyped for p.Gly47Arg mutations in the CECR1 gene using a Sequenom assay. The assay interrogated two mutant alleles of the first nucleotide of the Gly47 codon that both encode the glycine to arginine missense change.

\section{Results}

We found p.Gly47Arg mutations in 4 BD patients and 3 healthy controls. No individuals (neither cases or controls) carried two mutant alleles. The carrier frequency for p.Gly47Arg mutations was 0.002 in cases and in controls.

${ }^{1}$ Istanbul University Istanbul Medical Faculty, Internal Medicine Division of Rheumatology, Istanbul, Turkey

Full list of author information is available at the end of the article

\section{Conclusions}

These data show that the carrier rate of CECR1 p.Gly47Arg mutations is very low in Turkish Behcet's patients and not different from controls, suggesting no contribution to Behcet's disease.

\section{Authors' details}

${ }^{1}$ Istanbul University Istanbul Medical Faculty, Internal Medicine Division of Rheumatology, Istanbul, Turkey. ${ }^{2}$ National Institutes of Health, National Human Genome Research Institute, Bethesda, MD, USA. ${ }^{3}$ Istanbul University Institute of Experimental Medicine, Istanbul, Turkey. ${ }^{4}$ Istanbul University Istanbul Medical Faculty, Istanbul, Turkey. ${ }^{5}$ Istanbul University Cerrahpasa Medical Faculty, Istanbul, Turkey. ${ }^{6}$ National Institutes of Health, National Institutes of Arthritis Musculoskeletal and Skin Diseases, Bethesda, MD, USA.

Published: 28 September 2015

doi:10.1186/1546-0096-13-S1-P64

Cite this article as: Erer et al:: CECR1 p.Gly47Arg mutations are not increased in frequency in Turkish Behçet's disease patients compared with healthy controls. Pediatric Rheumatology 2015 13(Suppl 1):P64.

Submit your next manuscript to BioMed Central and take full advantage of:

- Convenient online submission

- Thorough peer review

- No space constraints or color figure charges

- Immediate publication on acceptance

- Inclusion in PubMed, CAS, Scopus and Google Scholar

- Research which is freely available for redistribution 